\title{
Do Socially Responsible Investment Funds Sell Losses and Ride Gains? The Disposition Effect in SRI Funds
}

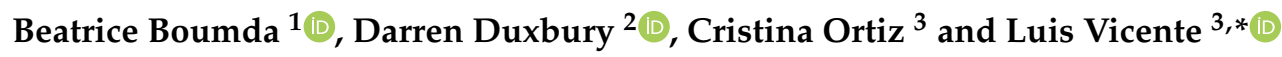 \\ 1 Accounting and Finance Department, University of Zaragoza, 50005 Zaragoza, Spain; \\ carolebeatrice@gmail.com \\ 2 Newcastle University Business School, Newcastle University, Newcastle upon Tyne NE4 5TG, UK; \\ darren.duxbury@ncl.ac.uk \\ 3 Accounting and Finance Department, IEDIS, University of Zaragoza, 50005 Zaragoza, Spain; cortiz@unizar.es \\ * Correspondence: lavicent@unizar.es; Tel.: +34-876554659
}

check for

updates

Citation: Boumda, B.; Duxbury, D.; Ortiz, C.; Vicente, L. Do Socially Responsible Investment Funds Sell Losses and Ride Gains? The Disposition Effect in SRI Funds Sustainability 2021, 13, 8142. https:// doi.org/10.3390/su13158142

Academic Editors: Maria Del Mar Miralles-Quirós and José Luis Miralles-Quirós

Received: 21 June 2021

Accepted: 19 July 2021

Published: 21 July 2021

Publisher's Note: MDPI stays neutral with regard to jurisdictional claims in published maps and institutional affiliations.

Copyright: (c) 2021 by the authors. Licensee MDPI, Basel, Switzerland. This article is an open access article distributed under the terms and conditions of the Creative Commons Attribution (CC BY) license (https:// creativecommons.org/licenses/by/ $4.0 /)$.

\begin{abstract}
An increasing percentage of the total net assets under professional management is devoted to ethical investments. Socially responsible investment (SRI) funds have a dual objective: building an investment strategy based on environmental, social, and corporate governance (ESG) screens and providing financial returns to investors. In the current study, we investigate whether this dual objective has an influence on the behavior of mutual fund managers in the realization of gains and losses. Evidence has shown that most investors in SRI funds invest in those funds primarily because of their social concerns. If the motivations of SRI managers align with those of SRI investors, SRI managers might then have more incentives than conventional managers to hold onto losing stocks if they feel their social value compensates for the economic loss. We hypothesize that SRI managers would be less prone to the disposition effect than conventional managers. Pertaining to the disposition effect, we do not find evidence of a difference in the behavior of SRI fund managers compared with that of conventional fund managers. Our results hold, even when considering market trends, management structure, gender, and prior performance.
\end{abstract}

Keywords: disposition effect; SRI mutual funds; portfolio managers

\section{Introduction}

The demand for socially responsible investment (SRI) funds has grown exponentially in the last two decades in all major financial markets in the world. According to the Global Sustainable Investment Alliance [1], in the five leading financial markets (Europe, United States, Japan, Canada, and Australia/New Zealand), sustainable investments rose from USD 22.8 trillion in 2016 to 30.6 trillion in 2018, a 34\% increase in only two years. More recently, US SFI Foundation-The Forum for Sustainable and Responsible Investment [2] reported a $42 \%$ increase in U.S.-domiciled assets under management using SRI strategies over two years: from USD 12 trillion at the beginning of 2018 to USD 17.1 trillion at the start of 2020. Stated otherwise, this report affirms that ethical investments represented one in three dollars of the total value of assets under professional management in 2020 (USD 51.4 trillion). The increasing demand for ethical investments converted what was once a niche market into a mainstream investment class.

An extensive body of literature focuses on evaluating the performance of SRI mutual funds in different financial markets, especially compared with conventional funds or against benchmarks. Some studies find that SRI funds and conventional funds present no significant differences in terms of returns [3,4]; others conclude that SRI funds earn higher returns [5,6]; yet others find that they underperform [7] (see Arefeen and Shimada [8] for a global literature review and Cunha et al. [9] for a global empirical analysis). Though it is true that SRI funds and conventional funds share similar financial objectives as they seek to find the optimum balance between risk and return, it is important to also look at 
the substantial difference between both types of funds. Besides the search for an adequate balance between risk and return, SRI mutual funds employ environmental, social, and corporate governance (ESG) screens to build their investment strategy. The dual objective of SRI mutual funds might have an influence, not only on their performance, but also on the behavior of their managers $[4,6,10]$.

Despite the long-standing arguments over the difference in performance of SRI funds and conventional funds, performance appears not to be the primary reason why retail investors hold SRI mutual funds. Riedl and Smeets [11] tested and confirmed through experiments that investors hold SRI funds primarily because of intrinsic social motives, whereas financial reasons play an important, albeit limited role. Other examples of experimental studies that find similar results are Barreda-Tarazona et al. [12], Apostolakis et al., [13] and Lagerkvist et al. [14].

Furthermore, Bollen [15], Benson and Humphrey [16], and Renneboog et al. [17] found that SRI investors are less sensitive than conventional investors to lagged poor performance and more likely than conventional investors to keep their investment despite poor results. Durán-Santomil et al. [18] determined that lagged sustainability scores significantly impact flows: Higher sustainability scores attract higher inflows into the fund. Similarly, Hartzmark and Susmann [19] analyzed U.S. mutual funds and concluded that investors value sustainability, as they find a direct link between being classified as low sustainability and obtaining net outflows and inversely, being classified as high sustainability resulted in net inflows.

The implications of non-financial aspects of SRI mutual funds might go beyond performance, flows and persistence of flows, and drive not only the behavior and expectations of retail investors, but also the behavior and expectations of SRI mutual fund managers, their trading patterns, and investment styles.

Originally coined by Shefrin and Statman [20], the term "disposition effect" refers to investors' tendency to sell appreciated stocks (winners) too soon, while riding depreciated stocks (losers) too long. The purchase price is set as a reference point for appreciation or depreciation. The disposition effect is a robust and well-documented anomaly that was investigated both at investor level and at aggregate level, both empirically and experimentally (see Cici [21] for a pioneer study on the disposition effect of mutual fund managers, Summers and Duxbury [22] for an example of experimental study, and Andreu et al. [23] as an example of a recent empirical study). The disposition effect has also been investigated in financial markets worldwide, for example, in the United States by Cici [21], in the United Kingdom by Richards et al. [24], in France by Boolell-Gunesh et al. [25], in Portugal by Leal et al. [26], in Taiwan by Lee et al. [27], and in China by Duxbury et al. [28] and An et al. [29].

Pertaining to the causes of the disposition effect, Shefrin and Statman [20] propose a theoretical framework that links the disposition effect to Kahneman and Tversky's [30] prospect theory and to mental accounting. Shefrin and Statman [20] propose regret aversion and a quest for pride as possible explanations for the disposition effect. Acknowledging that subsequent studies based on their work present prospect theory as the principal, if not the sole explanation behind the disposition effect, Shefrin [31] insists on the fact that prospect theory is a basis for studying the disposition effect but cannot serve as a unique explanation for its occurrence. Shefrin [31] warns against downplaying or disregarding the role of emotion-based explanations of the disposition effect, notably, the role of regret aversion.

Based on theoretical modelling, Barberis and Xiong [32] and Hens and Vlcek [33] reach the conclusion that prospect theory cannot explain the disposition effect. Although prospect theory is questioned in these works, they provide no alternative explanation. Summers and Duxbury [22] carried out several experiments that lead to the conclusion that specific emotional states are the drivers of the disposition effect: regret after a paper loss drives holding losers, while elation after a paper gain leads to selling winners.

Because SRI investors value the social utility derived from stocks more than their financial utility (as shown by Riedl and Smeets [11], for example), SRI fund managers might be more willing to hold onto losing stocks if they feel that the social value compensates for 
the financial loss in the eyes of investors. Given that regret aversion drives holding losers and elation drives selling winners, if the priorities of managers of SRI funds are aligned with the priorities of their investors, in other words, if they value the social utility of stocks over financial utility as their investors do, then the emotions derived from changes in prices of the stocks in their portfolio will be tempered. This will then lead to a lower disposition effect for SRI fund managers compared with conventional fund managers.

Furthermore, as supported by Kempf and Osthoff [4] and Gil-Bazo et al. [6], SRI fund managers trade less. As confirmed by Barber and Odean [34], overconfidence is associated with high trading volumes. Given that SRI fund managers trade less, they might be less susceptible to behavioral biases linked to trading and thus we might expect SRI fund managers to be less subject to the disposition effect.

Akin to the title of the work of Benson et al. [10]: "Do socially responsible fund managers really invest differently?" is the question to know whether SRI fund managers trade differently. Are SRI mutual fund managers prone to hold capital losses over capital gains? How do they compare with conventional mutual funds?

Based on these interrogations, our study has several hypotheses. In the first null hypothesis, we expect that SRI fund managers would not be subject to the disposition effect. In this case, their proportion of gains realized (PGR) should not be different than the proportion of losses realized (PLR).

Hypothesis 1 (H1). For SRI managers, proportion of gains realized = proportion of losses realized .

Our second null hypothesis states that, for conventional managers, the proportion of gains (PGR) realized should be equal to the proportion of losses realized (PLR).

Hypothesis 2 (H2). For conventional managers, proportion of gains realized $=$ proportion of losses realized.

The rejection of both $\mathrm{H} 1$ and $\mathrm{H} 2$ could lead to a potential disposition effect in both SRI and conventional managers, respectively, in the case that the proportion of gains realized were higher than the proportion of losses realized (PGR > PLR).

The third null hypothesis tests whether there are significant differences between the disposition effect of SRI managers and that of conventional managers. We hypothesize that the mean disposition spread (PGR-PLR) of SRI managers and conventional managers do not present significant differences.

Hypothesis 3 (H3). Disposition spread of SRI managers = Disposition Spread of conventional managers .

The rejection of $\mathrm{H} 3$ will conclude that the effect is different in SRI and conventional fund managers. In the case that $\mathrm{H} 1$ and $\mathrm{H} 2$ are not rejected, i.e., neither group of managers is found to exhibit the disposition effect, rejection of $\mathrm{H} 3$ would signify a difference in the realization of gains relative to losses across the two groups of managers, but not a difference in the strength of their disposition effects.

That we are aware of, the work of van Dooren and Galema [35] is the only study that investigates the disposition effect of socially responsible investors. In their study, they analyze individual investors' portfolios and conclude that social preferences have an impact on trading behavior. As far as we know, our study is the first to specifically investigate the disposition effect in SRI fund managers. Indeed, the literature has shown that the social inclinations of funds influence the trading volume of managers $[4,6]$, that SRI funds investors prioritize the social utility of funds over their financial utility [11] and that they are more likely to keep an investment despite poor performance [15-17]. It would then be interesting to know how well the behavior of SRI fund managers compares with that of conventional fund managers, and if the trading behavior of SRI fund managers is influenced by the social inclinations of their investors. 
The contribution of the current study to the existing literature is twofold. First, we contribute to the existing literature on behavioral biases, specifically the literature on the disposition effect by investigating whether the social orientation of funds has an impact on the trading behavior of managers. The link between retail investors' social preferences and the disposition effect [35] cannot be extrapolated to fund managers without a thorough analysis.

Secondly, we improve on the existing literature that compares SRI with conventional funds of dissimilar characteristics [4,6]. A similar methodology of creating a pool of conventional funds that match a sample of SRI funds is used by Gil-Bazo et al. [6] and Kempf and Osthoff [4]. In the current study, each SRI fund analyzed is matched with a conventional fund of similar characteristics (age, size, and global category). Though they do not match funds following a specific criterion, Kempf and Osthoff [4] point out that SRI funds tend to be younger and smaller in size than the average conventional fund; these characteristics might have an incidence on the trading patterns of fund managers.

We do not find evidence of the impact of socially responsible strategy on the disposition effect. Pertaining to the disposition effect, our investigation does not support the hypothesis of a difference in behavior for SRI fund managers, when compared with conventional fund managers. We obtain robust results, even when taking into consideration market trends, management structure, gender, and prior performance.

The remainder of the paper is organized as follows. Section 2 presents the data and the methodology used in the current study. Section 3 analyses the disposition effect of SRI and conventional fund managers. Section 4 concludes the paper.

\section{Data and Methods}

\subsection{Data}

Based on the data and the classification provided by Morningstar, we built a complete sample of U.S. equity funds of the following four global categories: U.S. Equity Large-Cap Blend, U.S. Equity Large-Cap Growth, U.S. Equity Large-Cap Value, and U.S. Equity MidCap. We use Morningstar's classification of sustainable investment to group funds into SRI funds or conventional funds. To carry out our analysis, we required a minimum of 5 consecutive monthly portfolios, which led to the exclusion of some SRI funds for not providing sufficient data for the analysis. Our analysis strictly required mutual funds that actively invest in equity; for this reason, index funds and funds of funds are excluded from the analysis. After applying the above filters, our database comprised 78 SRI mutual funds. For greater precision, we employed monthly portfolios to compute the disposition effect, hence, we exclude SRI funds that only report quarterly. Based on Elton et al. [36], using quarterly portfolio holdings for analyzing the behavior of equity mutual fund managers might result in distortions in the results obtained due to intra-quarter round trip trades. Our sample of SRI funds consists of funds domiciled in the United States during the period January 2005 to December 2020 and is free of survivorship bias.

To assess the impact of socially responsible screening on the disposition effect, we built a pool of conventional funds. For this purpose, we carefully matched each SRI fund to a conventional fund. We required that the SRI fund and the conventional fund match in terms of global category, size (measured by the average Total Net Assets of the fund during the entire period under study), and age (calculated from the inception date of the oldest share class). After filtering out SRI funds that do not report monthly portfolios, the final database comprised two sets of funds: 54 SRI mutual funds and 54 matched conventional funds.

Afterwards, we created a comprehensive database of the top 50 portfolio holdings with market values and numbers of shares for all the mutual funds in our sample and for each reporting period. These portfolio holdings employed are reported on a monthly basis. In their study, El Ghoul and Karoui [37] demonstrate when looking at the corporate social responsibility scores that the top 10 holdings are representative of the entire portfolio. In this study, we decided to use the top 50 holdings, first to provide more robust results by 
analyzing a wide range of holdings and secondly to avoid the bias of a potential window dressing effect. Indeed, given that the information about the top 10 holdings of funds is readily available to investors from financial media and from websites and brochures of asset management companies, it is more susceptible to portfolio manipulation, if any. Moreover, by employing the top 50 holdings and not the entire collection of holdings, we focused on the most representative stocks that might concurrently be the most significant to portfolio managers when building their strategy. Cash, cash equivalents, and derivative positions are excluded. The percentage of the top 50 portfolio holdings analyzed is a significant portion of the funds' portfolio and, on average, represents $80.59 \%$ of the total net asset (TNA) value of the funds in our sample.

Table 1 provides the descriptive statistics of our sample of SRI funds and conventional funds for the period January 2005 to December 2020. The information is provided for each of the four investment categories analyzed: U.S. Equity Large-Cap Blend, U.S. Equity Large-Cap Growth, U.S. Equity Large-Cap Value and U.S. Equity Mid-Cap, as well as the overall data for SRI funds and for conventional funds. In this study, we analyze more than 13,000 monthly portfolios, an average of more than 120 monthly portfolios per fund. The U.S. Equity Large-Cap Blend category holds the highest mean total assets both for SRI funds and for conventional funds. Because of our methodical matching process, there are no significant differences in terms of average total net assets neither within categories, nor between SRI funds and their conventional pair.

Table 1. Descriptive statistics.

\begin{tabular}{|c|c|c|c|c|c|c|}
\hline Global Category & $\begin{array}{l}\text { Num. of } \\
\text { Funds }\end{array}$ & $\begin{array}{l}\text { Num. of } \\
\text { Portfolios }\end{array}$ & $\begin{array}{c}\text { Mean Total } \\
\text { Net Assets } \\
\text { (In USD } \\
\text { Million) }\end{array}$ & $\begin{array}{c}\text { Mean Proportion } \\
\text { of TNA } \\
\text { Controlled with } \\
\text { Top } 50 \text { Holdings }\end{array}$ & $\begin{array}{c}\text { Mean Turnover } \\
\text { Ratio }\end{array}$ & $\begin{array}{c}\text { Mean } \\
\text { Performance } \\
\text { 3FF }\end{array}$ \\
\hline \multicolumn{7}{|l|}{ U.S. Equity Large-Cap } \\
\hline Non-SRI & 26 & 3346 & 1201 & $75.53 \%$ & $54.70 \%$ & $-0.0048(0.000)$ \\
\hline $\begin{array}{l}\text { SRI } \\
\text { U.S. Equity Large-Cap }\end{array}$ & 26 & 3483 & 1159 & $75.62 \%$ & $60.65 \%$ & $-0.0043(0.000)$ \\
\hline Non-SRI & 12 & 1488 & 763 & $84.35 \%$ & $83.77 \%$ & $-0.0045(0.000)$ \\
\hline $\begin{array}{l}\text { SRI } \\
\text { U.S. Equity Large-Cap }\end{array}$ & 12 & 1573 & 691 & $90.09 \%$ & $84.09 \%$ & $-0.0041(0.000)$ \\
\hline Value & & & & & & \\
\hline Non-SRI & 6 & 569 & 194 & $77.76 \%$ & $54.37 \%$ & $-0.0042(0.000)$ \\
\hline $\begin{array}{l}\text { SRI } \\
\text { U.S. Equity Mid-Cap }\end{array}$ & 6 & 424 & 170 & $96.13 \%$ & $66.90 \%$ & $-0.0036(0.000)$ \\
\hline Non-SRI & 10 & 1313 & 677 & $80.58 \%$ & $79.38 \%$ & $-0.0046(0.000)$ \\
\hline $\begin{array}{l}\text { SRI } \\
\text { All categories }\end{array}$ & 10 & 1050 & 632 & $88.82 \%$ & $49.46 \%$ & $-0.0042(0.000)$ \\
\hline Non-SRI & 54 & 6716 & 2835 & $78.67 \%$ & $66.16 \%$ & $-0.0046(0.000)$ \\
\hline SRI & 54 & 6530 & 2652 & $82.56 \%$ & $64.88 \%$ & $-0.0042(0.000)$ \\
\hline
\end{tabular}

Notes: This table reports the descriptive statistics for our sample for the period January 2005-December 2020. The data is presented for SRI funds and non-SRI funds and according to the global categories: U.S. Equity Large-Cap Blend, U.S. Equity Large-Cap Growth, U.S. Equity Large-Cap Value and U.S. Equity Mid-Cap. This table also provides information about the total number of funds, the total number of portfolios, the average total net assets (TNA), the mean proportion of TNA controlled with the top 50 holdings and the mean monthly turnover ratio calculated as the lesser of purchases or sales, divided by average monthly net assets. The last column reports the three-factor model alphas, with $p$-value using Newey-West robust standard errors in parentheses.

Table 1 also provides information about the average monthly turnover ratio of the funds in our sample. This information is obtained from Morningstar and extracted from annual reports of funds. Contrary to Kempf and Osthoff [4], and Gil-Bazo et al. [6], our results show that SRI funds and conventional funds present almost similar turnover ratios on average. Moreover, we find that the difference between their turnover ratios is highly variable depending on the investment category. We also notice that SRI funds present slightly higher turnover ratios in all categories, except for U.S. Equity Mid-Cap in which conventional funds exhibit a considerably higher average turnover ratio than SRI funds. In terms of average performance provided by Morningstar and based on the Fama and 
French [38] three-factor model, alphas are negative and close to zero in all categories and for the subsets of SRI funds and conventional funds. The average alphas of SRI funds are, nonetheless, slightly higher than the average alphas of conventional funds in all categories.

\subsection{Methods}

To evaluate whether fund managers are subject to the disposition effect, we calculated the disposition spread. The disposition spread is the difference between the proportion of gains realized and the proportion of losses realized. If a fund manager is subject to the disposition effect, the proportion of gains realized will be greater than the proportion of losses realized, thus resulting in a positive disposition spread (i.e., PGR > PLR).

To compute the disposition spread, the first step is to determine, for every stock held in the portfolio, whether a sale occurs within the reporting period. Hence, we need to determine two crucial elements in our computation: the purchase price that we set as reference point and the sales price. The difference between the cost and the current price will determine whether a position is at gain or at loss. Because the information about the intra-period trading of funds is not available and therefore, the exact moment during the month when a given transaction takes place cannot be determined, studies on the disposition effect either assume trades to occur sometime during the reporting period or at the end of the reporting period. Previous studies such as that of Cici [21] found consistent results when using average daily stock prices, based on the assumption that trades occur sometime during the reporting period, and when using the stock prices at the end of the reporting period, assuming trades occurs at the end of the reporting period. Following Andreu et al. [23], we suppose all trades occur at the end of the month. Thus, we assume the purchase price or the sales price to be the price at the end of the month. To calculate the sales price and the purchase price, we divide the reported market value of the specific stock by the number of shares, both values reported at the end of the month.

When final sales occur, i.e., when a fund exits the stock holding [39], we have no market value to determine the sales price; we then proceed differently. First, we attempt to recover the sales price at the end of the given month from another fund that holds these shares. If this is not possible, we obtain the end-of-month price of the shares from the database of Eikon.

In the current study, additional purchases are factored in using the average purchase price as inventory method. Odean [40] and Cici [21] document that results of investigations on the disposition effect are consistent even when using other inventory methods such as first in, first out (FIFO), high in, first out (HIFO) or last in, first out (LIFO).

We followed the ratio-based approach proposed by Odean [40] to compute the proportion of gains realized and the proportion of losses realized for each fund and for each reporting period. The proportion of gains realized $\left(P G R_{t}^{i}\right)$ and the proportion of losses realized $\left(P L R_{t}^{i}\right)$ are computed as follows, with $R G_{t}^{i}$ as realized capital gains, $U N R G_{t}^{i}$ as unrealized gains, $R L_{t}^{i}$ as realized losses, and $U N R L_{t}^{i}$ as unrealized losses:

$$
\begin{aligned}
P G R_{t}^{i} & =\frac{R G_{t}^{i}}{R G_{t}^{i}+U N R G_{t}^{i}} \\
P L R_{t}^{i} & =\frac{R L_{t}^{i}}{R L_{t}^{i}+U N R L_{t}^{i}}
\end{aligned}
$$

Computing $P G R_{t}^{i}$ and $P L R_{t}^{i}$ requires that their denominator be nonzero and that at least one sale takes place. The disposition spread (DISP) is the difference between the proportion of gains realized and the proportion of losses realized:

$$
D I S P_{t}^{i}=P G R_{t}^{i}-P L R_{t}^{i}
$$

A disposition spread greater (less) than zero implies that the manager has a propensity for selling gains (losses) more readily than losses (gains). A fund manager that is subject 
to the disposition effect will sell winning stocks more readily than losing stocks, thus obtaining a positive disposition spread (DISP).

\section{Empirical Analysis}

\subsection{The Disposition Effect of SRI Fund Managers and Conventional Fund Managers}

Table 2 reports the mean proportion of gains realized (PGR), the mean proportion of losses realized (PLR), and the mean disposition spread (DISP) of our entire sample and of the subsets of SRI and non-SRI funds. PGR, PLR, and DISP are computed for each fund monthly. In Panel A, the information is provided for the entire sample, and in Panel B, this same information is reported by fund category.

Table 2. The disposition spreads of SRI and of Non-SRI funds.

\begin{tabular}{|c|c|c|c|c|c|c|c|}
\hline \multicolumn{8}{|c|}{ Panel A: Full Sample } \\
\hline & ALL funds & SRI & Non-SRI & & & & \\
\hline PGR & 0.257 & 0.236 & 0.277 & & & & \\
\hline PLR & 0.288 & 0.282 & 0.295 & & & & \\
\hline DISP & $\begin{array}{l}-0.033 \\
(0.003)\end{array}$ & $\begin{array}{l}-0.047 \\
(0.000)\end{array}$ & $\begin{array}{l}-0.018 \\
(0.320)\end{array}$ & & & & \\
\hline$\%$ funds $>0$ & $26.9 \%$ & $27.8 \%$ & $25.9 \%$ & & & & \\
\hline $\begin{array}{l}\text { Chi-Square Test } \\
p \text {-value }\end{array}$ & \multicolumn{3}{|c|}{0.828} & & & & \\
\hline DIFF DISP & \multirow{2}{*}{\multicolumn{3}{|c|}{$\begin{array}{c}-0.028(0.167) \\
0.370\end{array}$}} & & & & \\
\hline Mann-Whitney & & & & & & & \\
\hline \multicolumn{8}{|c|}{ Panel B: Global Category } \\
\hline \multicolumn{4}{|c|}{ U.S. Equity Large-Cap Blend } & \multicolumn{4}{|c|}{ U.S. Equity Large-Cap Growth } \\
\hline & ALL funds & SRI & Non-SRI & & ALL funds & SRI & Non-SRI \\
\hline PGR & 0.279 & 0.247 & 0.310 & PGR & 0.254 & 0.241 & 0.266 \\
\hline PLR & 0.302 & 0.293 & 0.311 & PLR & 0.306 & 0.310 & 0.301 \\
\hline DISP & $\begin{array}{l}-0.025 \\
(0.200)\end{array}$ & $\begin{array}{l}-0.048 \\
(0.000)\end{array}$ & $\begin{array}{l}-0.002 \\
(0.975)\end{array}$ & DISP & $\begin{array}{l}-0.054 \\
(0.011)\end{array}$ & $\begin{array}{l}-0.072 \\
(0.071)\end{array}$ & $\begin{array}{l}-0.036 \\
(0.038)\end{array}$ \\
\hline$\%$ funds $>0$ & $23.1 \%$ & $19.2 \%$ & $26.9 \%$ & $\%$ funds $>0$ & $25 \%$ & $33.3 \%$ & $16.7 \%$ \\
\hline $\begin{array}{l}\text { Chi-Square Test } \\
p \text {-value }\end{array}$ & \multicolumn{3}{|c|}{0.510} & $\begin{array}{c}\text { Chi-Square Test } \\
p \text {-value }\end{array}$ & & \multicolumn{2}{|c|}{0.346} \\
\hline DIFF DISP & \multirow{2}{*}{\multicolumn{3}{|c|}{$\begin{array}{c}-0.046(0.211) \\
0.111\end{array}$}} & DIFF DISP & & \multicolumn{2}{|c|}{$-0.036(0.374)$} \\
\hline Mann-Whitney & & & & Mann-Whitney & & & \\
\hline \multicolumn{4}{|c|}{ U.S. Equity Large-Cap Value } & \multicolumn{4}{|c|}{ U.S. Equity Mid-Cap } \\
\hline & ALL funds & SRI & Non-SRI & & ALL funds & SRI & Non-SRI \\
\hline PGR & \multirow{3}{*}{$\begin{array}{c}0.212 \\
0.213 \\
-0.001 \\
(0.968)\end{array}$} & 0.221 & \multirow{3}{*}{$\begin{array}{c}0.204 \\
0.208 \\
-0.0004 \\
(0.849)\end{array}$} & PGR & 0.230 & 0.214 & \multirow{3}{*}{$\begin{array}{c}0.247 \\
0.295 \\
-0.050 \\
(0.018)\end{array}$} \\
\hline PLR & & 0.218 & & PLR & 0.276 & 0.258 & \\
\hline DISP & & $0.005(0.906)$ & & DISP & $\begin{array}{l}-0.047 \\
(0.003)\end{array}$ & $\begin{array}{l}-0.044 \\
(0.086)\end{array}$ & \\
\hline \multirow{2}{*}{$\begin{array}{l}\% \text { funds }>0 \\
\text { Chi-Square Test } \\
p \text {-value }\end{array}$} & \multirow[t]{2}{*}{$58.3 \%$} & \multirow[t]{2}{*}{$66.7 \%$} & \multirow[t]{2}{*}{$50 \%$} & $\%$ funds $>0$ & $20 \%$ & $20 \%$ & \multirow[t]{2}{*}{$20 \%$} \\
\hline & & & & $\begin{array}{c}\text { Chi-Square Test } \\
p \text {-value }\end{array}$ & & 1.000 & \\
\hline DIFF DISP & & \multirow{2}{*}{\multicolumn{2}{|c|}{$\begin{array}{c}0.006(0.865) \\
0.873\end{array}$}} & DIFF DISP & & \multirow{2}{*}{\multicolumn{2}{|c|}{$\begin{array}{c}0.006(0.849) \\
0.821\end{array}$}} \\
\hline Mann-Whitney & & & & Mann-Whitney & & & \\
\hline
\end{tabular}

Notes: This table reports the general disposition data for the subsets of SRI funds and non-SRI funds: the mean proportion of gains realized (PGR), the mean proportion of losses realized (PLR) and the mean disposition spread (DISP) for our entire sample in Panel A and by category in Panel B. Additionally, for each panel and category, Table 2 provides information about the percentage of funds with a positive mean disposition spread, about the Chi-Square Test used to assess the difference in the proportion of funds with a DISP $>0$ for SRI and non-SRI subsets and about the difference between the mean disposition spread of SRI and non-SRI funds (DIFF DISP), with $p$-value using $t$-test in parentheses and in the last rows, $p$-value using the Mann-Whitney test.

For the entire sample of funds in our study, we found a negative and significant average disposition spread (-0.033). Rather than suggesting a widespread disposition effect, these results imply that on average, equity mutual funds managers show a preference for realizing losses rather than gains. When the sample is divided into SRI funds and conventional funds, SRI funds appear to significantly realize losses more readily than gains, more specifically in the U.S. Equity Large-Cap Blend category $(-0.048)$. 
Therefore, we reject hypothesis $\mathrm{H} 1$ that states that SRI fund managers realize gains and losses similarly. Given that SRI managers present a negative disposition spread, this behavior is, however, not compatible with the disposition effect. On the other hand, we fail to reject hypothesis $\mathrm{H} 2$ that states that conventional managers display the same behavior towards appreciated stocks and depreciated stocks. In other words, we do not find a difference in behavior in the realization of gains and the realization of losses for conventional managers, but we find a clear pattern in SRI portfolios of the U.S. Equity Large-Cap Blend category for the realization of losses over gains, which is just the reverse of a disposition effect.

Another important statistic provided by Table 2 is the percentage of funds with a mean positive disposition spread (26.9\%). For the sample as a whole, less than one in three funds have a mean positive disposition spread. This is true for all categories except for U.S. Equity Large-Cap Value funds, where the percentage of funds with a positive disposition spread peaks: $66.7 \%$ SRI funds belonging to this category present a mean disposition spread greater than 0 . In terms of proportion of funds with a positive disposition spread, no significant difference is found between SRI and conventional funds, based on the Chi-Square Test in any of the categories.

Additionally, we found the differences between the disposition spreads of SRI fund managers and non-SRI fund managers to be negative $(-0.028)$ for the sample as a whole and for two categories: U.S. Equity Large-Cap Blend and U.S. equity Large-Cap Growth, implying that in these cases, SRI fund managers display a stronger preference than nonSRI fund managers for realizing losses rather than gains. However, neither the positive differences nor the negative differences are statistically significant. We thus fail to reject hypothesis $\mathrm{H} 3$, indicating that there is an absence of difference between SRI fund managers and conventional fund managers in the realization of losses relative to gains.

Generally, our results are consistent with Cici [21]. By and large, we do not find evidence of disposition effect in equity mutual funds. Furthermore, by using higher frequency data than Cici [21] and by differentiating between SRI and conventional funds, we find that there is no significant difference between the mean disposition spread of SRI funds and that of conventional funds, even when separating funds by investment categories. This absence of significant difference between the disposition spreads of SRI and non-SRI managers questions that alternative motives, such as social responsibility, significantly affect the elation (regret) felt by SRI fund managers in case of gains (losses) in comparison with conventional fund managers. Pertaining to the disposition effect, we do not find differences in trading behavior between SRI fund managers and conventional fund managers.

\subsection{Internal, External and Fund-Related Factors}

Previous studies have established a link between the disposition effect and market trends (such as Leal et al. [26]), management characteristics (Cici [21], for instance), or prior performance (An et al. [29], Duxbury et al. [28], for example). In this part of our study, we examine through multiple lenses whether our results still hold, i.e., whether the null difference between the disposition spreads of SRI fund managers and conventional fund managers is robust when taking internal, external, and fund-related parameters into consideration.

\subsubsection{Results Structured by Market Trends}

Kim and Nofsinger [41] found evidence of differences in the behavior of individual investors in bull periods compared with their behavior in bear periods in the Japanese market. Investigating the impact of the state of the market could potentially unveil other aspects of the disposition effect. As suggested by Odean [40], in a general scenario of rising prices, investors might tend to sell more winning stocks, because they have more opportunities to do so, given that several stocks in their portfolio have appreciated. In congruence with Odean's [40] argument, Leal et al. [26] expected momentum in bullish 
periods and contrarian behaviors in bearish periods, but they found evidence of stronger disposition effect during bull periods in the Portuguese market. Thus, a question arises in our analysis on the possibility of differences in the realization of gains and losses for SRI mutual fund managers compared with conventional managers under different market trends.

To successfully detect the bull/bear phases for the benchmark S\&P 500, we implemented the algorithm designed by Bry and Boschan [42] and replicated in Pagan and Soussonov [43]. Based on this methodology, we identified the following bull periods for the time frame of the current study: January 2005 to October 2007, March 2009 to April 2011, October 2011 to May 2015, and October 2015 to December 2020. We also identified the following bear periods: November 2007 to February 2009, May 2011 to September 2011, and June 2015 to September 2015.

Table 3, Panel A provides information about the state of the U.S. equity market and the disposition effect for our entire sample. Our results suggest a general tendency to sell more losses than gains for both bullish and bearish markets. To be more specific, we obtain a disposition spread of -0.035 for bullish markets and -0.005 for bearish markets.

Table 3. The disposition spreads by market trends.

\begin{tabular}{|c|c|c|c|c|}
\hline \multicolumn{5}{|c|}{ Panel A: Full Sample } \\
\hline & \multicolumn{2}{|l|}{ Bullish } & \multicolumn{2}{|l|}{ Bearish } \\
\hline PGR & \multicolumn{2}{|l|}{0.255} & \multicolumn{2}{|l|}{0.293} \\
\hline PLR & 0.289 & \multicolumn{3}{|c|}{0.298} \\
\hline DISP & $-0.035(0.001)$ & \multicolumn{3}{|c|}{$-0.005(0.017)$} \\
\hline \# months & 108 & \multicolumn{3}{|c|}{78} \\
\hline DIFF DISP & \multirow{2}{*}{\multicolumn{4}{|c|}{$\begin{array}{l}-0.031(0.097) \\
0.088\end{array}$}} \\
\hline Mann-Whitney & & & & \\
\hline \multicolumn{5}{|c|}{ Panel B: Market Trend and Investment Orientation } \\
\hline & \multicolumn{2}{|c|}{ Bullish } & \multicolumn{2}{|c|}{ Bearish } \\
\hline & SRI & Non-SRI & SRI & Non-SRI \\
\hline PGR & 0.235 & 0.275 & 0.241 & 0.335 \\
\hline PLR & 0.282 & 0.297 & 0.265 & 0.326 \\
\hline DISP & $-0.049(0.000)$ & $-0.022(0.232)$ & $-0.024(0.052)$ & $0.012(0.711)$ \\
\hline DIFF DISP & \multirow{2}{*}{\multicolumn{2}{|c|}{$\begin{array}{c}-0.027(0.198) \\
0.503\end{array}$}} & \multicolumn{2}{|c|}{$-0.036(0.225)$} \\
\hline Mann-Whitney & & & & \\
\hline \multicolumn{5}{|c|}{$\begin{array}{l}\text { Notes: This table presents the mean proportion of gains realized (PGR), the mean proportion of losses realized } \\
\text { (PLR) and the mean disposition spreads (DISP), for the entire sample in Panel A and for the subsets of SRI funds } \\
\text { and non-SRI funds depending on the market trend in Panel B. This table also provides information about the } \\
\text { number of months for each market trend and reports for each panel, the difference between the mean disposition } \\
\text { spreads by market trend and for each subset, with } p \text {-values using } t \text {-test in parentheses and in the last rows } \\
p \text {-values using Mann-Whitney test. }\end{array}$} \\
\hline
\end{tabular}

More interestingly, when discriminating between SRI funds and conventional funds, as per Table 3, Panel B, we find a disposition spread of -0.049 , which implies that SRI funds exhibit a greater tendency to sell losses than gains and this tendency is strong and significant under bull market conditions. Conventional funds, on the other hand, do not present any significant pattern. However, the lack of significant difference in the disposition spreads of SRI and conventional funds remains under both market conditions.

Consequently, under bullish trends of the markets, we reject hypothesis H1 that supports that SRI managers display the same behavior when faced with losses and when faced with gains. Given the negative disposition spread, this behavior is however not consistent with the disposition effect. Conversely, we fail to reject $\mathrm{H} 2$, the hypothesis of a difference in the realization of losses and gains for conventional fund managers in a scenario of general upward trend in stock prices. Finally, we fail to reject H3, the hypothesis of a difference in behavior between SRI fund managers and conventional fund managers in bullish trends.

On the other hand, under bearish trends, we fail to reject hypotheses $\mathrm{H1}, \mathrm{H} 2$, and $\mathrm{H} 3$. Indeed, neither SRI fund managers nor conventional fund managers present significant 
differences in their realization of losses and gains and there is no significant difference between both groups in a scenario of general downward trend in stock prices.

\subsubsection{Results Structured by Management Characteristics}

Pertaining to the relationship between the disposition effect and teams, as suggested by Cici [21], two conflicting hypotheses arise. First, because of group objectivity, every single member of the team would feel less attached to the stocks held in the fund portfolio, thus leading to a mitigation of the disposition effect. Shefrin [31] and Summers and Duxbury [22] insist on the role of regret as a catalyst for the disposition effect. Contrariwise, based on the prime role of emotions in the onset of the disposition effect demonstrated by Summers and Duxbury [22], it is possible that emotions become more extreme due to groupthink [44]. Consequently, the behavior of teams would be intensified compared with individuals and this would lead to a stronger disposition effect. Cici [21] and Rau [45] found evidence, in real life and in a laboratory-type experiment, respectively, that teams display a stronger disposition effect than individuals. Andreu et al. [23], on the other hand, found no significant difference between the disposition effect in teams and in single managers.

In Panel A of Table 4, we report the statistics for the entire sample according to management structure. First, we notice that approximately two in three funds are managed by teams. We also find that, although teams present lower proportions of gains realized $(0.260)$ and losses realized $(0.295)$ than single managers ( 0.289 and 0.315 , respectively), the former have a greater and stronger tendency to realize losses rather than gains. In addition, we observe that, although teams present a wider disposition spread than single managers, the difference between their disposition spreads $(-0.010)$ is not statistically significant.

Table 4. The disposition spreads by management structure and gender.

\begin{tabular}{|c|c|c|c|c|}
\hline \multicolumn{5}{|c|}{ Panel A: Full Sample } \\
\hline & \multicolumn{2}{|c|}{ Structure } & \multicolumn{2}{|c|}{ Gender } \\
\hline & TEAM & SOLO & MALE & FEMALE \\
\hline PGR & 0.260 & 0.289 & 0.288 & 0.241 \\
\hline PLR & 0.295 & 0.315 & 0.313 & 0.292 \\
\hline DISP & $-0.036(0.002)$ & $-0.026(0.019)$ & $-0.025(0.030)$ & $-0.052(0.078)$ \\
\hline \# funds & 99 & 55 & 52 & 6 \\
\hline DIFF DISP & -0.01 & $.522)$ & 0.02 & $342)$ \\
\hline Mann-Whitney & & & & \\
\hline \multicolumn{5}{|c|}{ Panel B: Management Structure and Investment Orientation } \\
\hline & \multicolumn{2}{|c|}{ TEAM } & \multicolumn{2}{|c|}{ SOLO } \\
\hline & SRI & Non-SRI & SRI & Non-SRI \\
\hline PGR & 0.241 & 0.278 & 0.259 & 0.330 \\
\hline PLR & 0.292 & 0.297 & 0.294 & 0.344 \\
\hline DISP & $-0.052(0.000)$ & $-0.019(0.329)$ & $-0.037(0.038)$ & $-0.014(0.291)$ \\
\hline DIFF DISP & -0.03 & $.154)$ & -0.0 & .246) \\
\hline Mann-Whitney & & & & \\
\hline \multicolumn{5}{|c|}{ Panel C: Gender and Investment Orientation } \\
\hline & \multicolumn{2}{|c|}{ MALE } & \multicolumn{2}{|c|}{ FEMALE } \\
\hline & SRI & Non-SRI & SRI & Non-SRI \\
\hline PGR & 0.269 & 0.314 & 0.183 & 0.299 \\
\hline PLR & 0.301 & 0.330 & 0.226 & 0.358 \\
\hline DISP & $-0.034(0.067)$ & $-0.013(0.265)$ & $-0.043(0.308)$ & $-0.061(0.278)$ \\
\hline DIFF DISP & \multirow{2}{*}{\multicolumn{2}{|c|}{$\begin{array}{c}-0.021(0.350) \\
0.374\end{array}$}} & \multirow{2}{*}{\multicolumn{2}{|c|}{$\begin{array}{c}0.018(0.742) \\
0.275\end{array}$}} \\
\hline Mann-Whitney & & & & \\
\hline \multicolumn{5}{|c|}{$\begin{array}{l}\text { Notes: This table presents the mean proportion of gains realized (PGR), the mean proportion of losses realized } \\
\text { (PLR) and the mean disposition spreads (DISP), for the entire sample in Panel A, for the subsets of SRI funds and } \\
\text { non-SRI funds depending on management structure in Panel B and for the subsets of SRI funds and non-SRI funds } \\
\text { depending on gender in Panel C. This table also provides information about the number of funds by management } \\
\text { structure and by gender and reports for each panel, the differences between the mean disposition spreads of the } \\
\text { subsets, with } p \text {-value using } t \text {-test in parentheses and in the last rows, } p \text {-value using Mann-Whitney test. }\end{array}$} \\
\hline
\end{tabular}


Panel B presents the statistics of team and single managers based on their investment orientation. Results are consistent with Panel A. Our findings suggest that SRI funds, especially team-managed SRI funds, are more reluctant to realize gains rather than losses. Nonetheless and consistent with our previous results, the difference between SRI and conventional funds in terms of disposition spread $(-0.032)$ is not significant. In other words, SRI and conventional funds do not present any significant differences in disposition effect when considering management structure.

We reject hypothesis H1, as both team-managed and solo-managed portfolios reveal a tendency for SRI fund managers to realize more losses than gains. Consistent with our previous findings, the behavior is not consistent with the disposition effect in SRI fund managers. We fail to reject hypothesis $\mathrm{H} 2$, suggesting that we do not find evidence of a difference in the realization of losses and gains for conventional managers in teams or individually. Finally, we fail to reject hypothesis H3, given that there is no evidence of a difference of behavior between conventional managers and SRI managers when comparing based on management structure.

Pioneer studies in the field of behavioral finance have revealed different trading patterns for men and for women. Barber and Odean [34], for instance, establish that men trade more frequently than women. Rau [46] analyzes gender differences in the disposition effect and finds that women present higher disposition effects than men, probably due to stronger loss aversion. Pertaining to the disposition effect, Talpsepp [47] does not find any significant differences between men and women.

From the statistics presented in Panel A, there is a gender asymmetry: only one in ten funds in our sample is managed by a woman. Panel C shows that male fund managers, and especially male managers of SRI funds, might have a higher tendency to realize losses rather than gains. However, we do not find a significant difference when comparing male managers of SRI funds with male managers of conventional funds $(-0.021)$. Contrary to Rau [46], we do not find women to be reluctant to sell stocks below their reference prices. In the same manner as Talpsepp [47], we do not find any significant difference in the disposition effect for our sample based on gender. More importantly, when looking at gender, SRI and conventional funds do not exhibit any significant differences in terms of disposition effect.

Therefore, when taking gender into account, we fail to reject hypotheses H1, H2, and H3. Based on our findings, neither male fund managers nor female fund managers, across both SRI and conventional groups, present significant differences in terms of the relative realization of gains and losses. Similarly, there appears to be no difference between male SRI fund managers and female SRI fund managers when compared with their respective counterparts.

\subsubsection{Prior Performance and the Disposition Effect}

Along the lines of the general state of the market, the performance of the entire portfolio might have an influence on the fund managers' behavior and prompt them to sell gains more readily than losses. An et al. [29] found a significant relationship between the disposition effect of retail investors and the performance of their portfolio. They found that when the portfolio is performing poorly, the investor is more likely to succumb to the disposition effect. Duxbury et al. [28] found that that house money effect (in the form of risk seeking/aversion following prior realized gains/losses) moderates the tendency of investors to succumb to the disposition effect.

To evaluate the relationship between prior performance and the disposition effect, we perform a logistic regression with the disposition effect as a dependent variable and 1-month lagged Fama and French [38] alpha for the last 60 daily observations as an explanatory variable. The disposition effect is a dummy variable that takes the value 1 in the presence of disposition effect and 0 otherwise. The results of the logistic regression are presented in Table 5. 
Table 5. Logit regression of disposition effect and 3-month prior performance.

\begin{tabular}{lccc}
\hline & ALL Funds & SRI & Non-SRI \\
\hline $\begin{array}{l}\text { Panel A: Fixed effects: } \\
\text { No }\end{array}$ & $10.786(0.364)$ & $17.612(0.268)$ & $2.524(0.888)$ \\
\hline $\begin{array}{l}\text { Coef. } \\
\text { Num. of funds }\end{array}$ & 107 & 53 & 54 \\
Num. of portfolios & 10,052 & 5142 & 4910 \\
\hline $\begin{array}{l}\text { Panel B: Fixed effects: } \\
\text { Yes }\end{array}$ & \multicolumn{4}{l}{} \\
\hline $\begin{array}{l}\text { Coef. } \\
\text { Num. of funds }\end{array}$ & $7.394(0.552)$ & $12.584(0.482)$ & $1.147(0.951)$ \\
Num. of portfolios & 8310 & 38 & 37 \\
\hline $\begin{array}{l}\text { Notes: This table summarizes the output of our logistic regression model. Estimated coefficients are given with } \\
p \text {-values in parentheses. The reduced frequency in the number of funds and number of portfolios in the fixed } \\
\text { effects models is due the fact that the model drops some funds because of all positive or all negative outcomes. }\end{array}$
\end{tabular}

While our findings are not directly comparable to Duxbury et al. [28], contrary to An et al. [29], we do not find any significant relationship between the 3-month prior performance of mutual fund managers and the disposition effect, nor do we find a significant difference in the probability to succumb to the disposition effect when belonging either to SRI group, or to the conventional group. Our results are consistent when using 6-month prior performance. In other words, based on our results, we do not find any significant difference in the probability of SRI equity mutual fund managers to succumb to the disposition effect when compared with their conventional counterparts, even when taking prior performance into consideration. There is no evidence of a link between prior performance and the realization of gains relative to losses for SRI fund managers, nor for conventional managers.

\section{Conclusions}

Ethical investments now represent both an increasing and important share of the investment markets in the United States. While several studies have investigated the difference in performance of SRI funds compared to conventional funds, performance appears not to be the prime reason why investors hold SRI funds. Many authors found evidence showing that investors in SRI funds are primarily motivated by their social responsibility, that they are less sensitive to poor performance, and that they are more likely to keep an investment in a fund despite poor performance.

Do the social responsibility of their fund and the expectations of their investors influence how SRI fund managers realize losses and gains? In this study, we test several null hypotheses: there is no difference in the proportion of gains realized (PGR) and the proportion of losses realized (PLR), (H1) for SRI managers and (H2) for conventional managers. Finally, we also test the null hypothesis (H3) that SRI fund managers and conventional fund managers do not present significant differences in terms of disposition spreads (PGR-PLR).

Consistent with Cici [21], we do not find evidence of a widespread disposition effect in equity mutual funds. Furthermore, the results of our investigation support the idea that there is no significant difference in the behavior of SRI and conventional fund managers in terms of disposition effect. Interestingly, we do find that SRI fund managers might be more prone to realize losses rather than gains, especially in the U.S. Equity Large-Cap Blend category. Despite their social responsibility, when compared with conventional fund managers, SRI mutual fund managers do not exhibit a different pattern of behavior when facing losses and gains.

Based on our findings, we conclude that we reject hypothesis H1, given that SRI managers tend to realize more losses than they realize gains. This behavior is, however, not consistent with the disposition effect. We also fail to reject hypothesis $\mathrm{H} 2$, as there is no evidence of differences in the realization of losses and gains for conventional managers. 
Finally, we fail to reject hypothesis H3: there is no significant difference between SRI managers and conventional managers, pertaining to the realization of losses and gains.

Our investigation confirms that, despite the added social preference of investors in SRI funds, SRI and conventional fund managers behave similarly when realizing losses and gains and thus might have the same motivation when taking trading decisions. The results obtained in the current study are robust for different investment categories and when taking into consideration market trends, management structure, gender, and prior performance.

More specific results could be obtained with monthly portfolios of all the SRI funds and the investigation was performed on the entire sample of SRI funds. Furthermore, more precise findings could be obtained with detailed information about the moment when trade takes place. Further analyses are warranted to determine whether the ESG scores of stocks influence their tendency to being disposed of.

Author Contributions: Conceptualization, B.B., D.D., C.O. and L.V.; Formal analysis, B.B., D.D., C.O. and L.V.; Investigation, B.B.; Methodology, B.B., D.D., C.O. and L.V.; Resources, B.B.; Supervision, D.D., C.O. and L.V.; Writing—original draft, B.B.; Writing—review and editing, D.D., C.O. and L.V. All authors have read and agreed to the published version of the manuscript.

Funding: This research was funded by Ministerio de Ciencia, Innovación y Universidades (MCIU, Spanish Government), Agencia Estatal de Investigación (AEI), Fondo Europeo de Desarrollo Regional (FEDER), grant number RTI2018-093483-B-I00, and Gobierno de Aragón, grant number CIBER S38_17R.

Institutional Review Board Statement: Not applicable.

Informed Consent Statement: Not applicable.

Data Availability Statement: The datasets generated and/or analyzed during the current study may be available from the corresponding author on reasonable request.

Conflicts of Interest: The authors declare no conflict of interest.

\section{References}

1. GSIA. 2018 Global Sustainable Investment Review. Available online: http:/ / www.gsi-alliance.org/wp-content/uploads/2019/0 6/GSIR_Review2018F.pdf (accessed on 26 March 2021).

2. US SFI Foundation: The Forum for Sustainable and Responsible Investment. 2020 Report on U.S. Sustainable and Impact Investing Trends. Available online: https:/ / www.ussif.org/files/US\%20SIF\%20Trends\%20Report\%202020\%20Executive\%20Summary.pdf (accessed on 26 March 2021).

3. Bauer, R.; Koedijk, K.; Otten, R. International evidence on ethical mutual fund performance and investment style. J. Bank. Financ. 2005, 29, 1751-1767. [CrossRef]

4. Kempf, A.; Osthoff, P. SRI funds: Nomen est omen. J. Bus. Financ. Account. 2008, 35, 1276-1294. [CrossRef]

5. Kempf, A.; Osthoff, P. The effect of socially responsible investing on portfolio performance. Eur. Financ. Manag. 2007, 13, 908-922. [CrossRef]

6. Gil-Bazo, J.; Ruiz-Verdú, P.; Santos, A.A. The performance of socially responsible mutual funds: The role of fees and management companies. J. Bus. Ethics 2010, 94, 243-263. [CrossRef]

7. Renneboog, L.; Ter Horst, J.; Zhang, C. Socially responsible investments: Institutional aspects, performance, and investor behavior. J. Bank. Financ. 2008, 32, 1723-1742. [CrossRef]

8. Arefeen, S.; Shimada, K. Performance and Resilience of socially responsible investing (SRI) and conventional funds during different shocks in 2016: Evidence from Japan. Sustainability 2020, 12, 540. [CrossRef]

9. de Souza Cunha, F.A.F.; de Oliveira, E.M.; Orsato, R.J.; Klotzle, M.C.; Cyrino Oliveira, F.L.; Caiado, R.G.G. Can sustainable investments outperform traditional benchmarks? Evidence from global stock markets. Bus. Strategy Environ. 2020, $29,682-697$. [CrossRef]

10. Benson, K.L.; Brailsford, T.J.; Humphrey, J.E. Do socially responsible fund managers really invest differently? J. Bus. Ethics 2006, 65, 337-357. [CrossRef]

11. Riedl, A.; Smeets, P. Why do investors hold socially responsible mutual funds? J. Financ. 2017, 72, 2505-2550. [CrossRef]

12. Barreda-Tarrazona, I.; Matallín-Sáez, J.C.; Balaguer-Franch, M.R. Measuring Investors' Socially Responsible Preferences in Mutual Funds. J. Bus. Ethics 2011, 103, 305-330. [CrossRef]

13. Apostolakis, G.; van Dijk, G.; Kraanen, F.; Blomme, R.J. Examining socially responsible investment preferences: A discrete choice conjoint experiment. J. Behav. Exp. Financ. 2018, 17, 83-96. [CrossRef] 
14. Lagerkvist, C.J.; Edenbrandt, A.K.; Tibbelin, I.; Wahlstedt, Y. Preferences for sustainable and responsible equity funds-A choice experiment with Swedish private investors. J. Behav. Exp. Financ. 2020, 28, 100406. [CrossRef]

15. Bollen, N.P. Mutual fund attributes and investor behavior. J. Financ. Quant. Anal. 2007, 683-708. [CrossRef]

16. Benson, K.L.; Humphrey, J.E. Socially responsible investment funds: Investor reaction to current and past returns. J. Bank. Financ. 2008, 32, 1850-1859. [CrossRef]

17. Renneboog, L.; Ter Horst, J.; Zhang, C. Is ethical money financially smart? Nonfinancial attributes and money flows of socially responsible investment funds. J. Financ. Intermediat. 2011, 20, 562-588. [CrossRef]

18. Durán-Santomil, P.; Otero-González, L.; Correia-Domingues, R.H.; Reboredo, J.C. Does sustainability score impact mutual fund performance? Sustainability 2019, 11, 2972. [CrossRef]

19. Hartzmark, S.M.; Sussman, A.B. Do investors value sustainability? A natural experiment examining ranking and fund flows. J. Financ. 2019, 74, 2789-2837. [CrossRef]

20. Shefrin, H.; Statman, M. The disposition to sell winners too early and ride losers too long: Theory and evidence. J. Financ. 1985, 40, 777-790. [CrossRef]

21. Cici, G. The prevalence of the disposition effect in mutual funds' trades. J. Financ. Quant. Anal. 2012, 47, 795-820. [CrossRef]

22. Summers, B.; Duxbury, D. Decision-dependent emotions and behavioral anomalies. Organ. Behav. Hum. Decis. Process 2012, 118, 226-238. [CrossRef]

23. Andreu, L.; Ortiz, C.; Sarto, J.L. Disposition effect in fund managers. Fund and stock-specific factors and the upshot for investors. J. Econ. Behav. Organ. 2020, 176, 253-268. [CrossRef]

24. Richards, D.W.; Rutterford, J.; Kodwani, D.; Fenton-O'Creevy, M. Stock market investors' use of stop losses and the disposition effect. Eur. J. Financ. 2017, 23, 130-152. [CrossRef]

25. Boolell-Gunesh, S.; Broihanne, M.H.; Merli, M. Disposition effect, investor sophistication and taxes: Some French Specificities. Finance 2009, 30, 51-78. [CrossRef]

26. Leal, C.C.; Armada, M.J.R.; Duque, J.C. Are all individual investors equally prone to the disposition effect all the time? New evidence from a small market. Front. Financ. Econ. 2010, 7, 38-68.

27. Lee, J.S.; Yen, P.H.; Chan, K.C. Market states and disposition effect: Evidence from Taiwan mutual fund investors. Appl. Econ. 2013, 45, 1331-1342. [CrossRef]

28. Duxbury, D.; Hudson, R.; Keasey, K.; Yang, Z.; Yao, S. Do the disposition and house money effects coexist? A reconciliation of two behavioral biases using individual investor-level data. J. Int. Financ. Mark. Inst. Money 2015, 34, 55-68. [CrossRef]

29. An, L.; Engelberg, J.; Henriksson, M.; Wang, B.; Williams, J. The Portfolio-Driven Disposition Effect. (Unpublished, 2019 Version). Available online: https:/ / papers.ssrn.com/sol3/papers.cfm?abstract_id=3126997 (accessed on 26 March 2021).

30. Kahneman, D.; Tversky, A. Prospect Theory: An Analysis of Decision under Risk. Econometrica 1979, 47, 263-292. [CrossRef]

31. Shefrin, H. How the disposition effect and momentum impact investment professionals. J. Investig. Consult. 2007, 8, 68-79.

32. Barberis, N.; Xiong, W. What drives the disposition effect? An analysis of a long-standing preference-based explanation. J. Financ. 2009, 64, 751-784. [CrossRef]

33. Hens, T.; Vlcek, M. Does prospect theory explain the disposition effect? J. Behav. Financ. 2011, 12, 141-157. [CrossRef]

34. Barber, B.M.; Odean, T. Boys will be boys: Gender, overconfidence, and common stock investment. Q. J. Econ. 2001, 116, 261-292. [CrossRef]

35. van Dooren, B.; Galema, R. Socially responsible investors and the disposition effect. J. Behav. Exp. Financ. 2018, 17, 42-52. [CrossRef]

36. Elton, E.; Gruber, M.; Blake, C.R.; Krasny, Y.; Ozelge, S. The effect of holdings data frequency on conclusions about mutual fund behavior. J. Bank. Financ. 2010, 34, 912-922. [CrossRef]

37. El Ghoul, S.; Karoui, A. Does corporate social responsibility affect mutual fund performance and flows? J. Bank. Financ. 2017, 77, 53-63. [CrossRef]

38. Fama, E.F.; French, K.R. Common risk factors in the returns on stocks and bonds. J. Financ. Econ. 1993, 33, 3-56. [CrossRef]

39. Badrinath, S.G.; Wahal, S. Momentum trading by institutions. J. Financ. 2002, 57, 2449-2478. [CrossRef]

40. Odean, T. Are investors reluctant to realize their losses? J. Financ. 1998, 53, 1775-1798. [CrossRef]

41. Kim, K.A.; Nofsinger, J.R. The behavior of Japanese individual investors during bull and bear markets. J. Behav. Financ. 2007, 8, 138-153. [CrossRef]

42. Bry, G.; Boschan, C. Cyclical Analysis of Time Series: Selected Procedures and Computer Programs; National Bureau of Economic Research: Cambridge, MA, USA; Columbia University Press: New York, NY, USA, 1971.

43. Pagan, A.R.; Sossounov, K.A. A simple framework for analysing bull and bear markets. J. Appl. Econ. 2003, 18, 23-46. [CrossRef]

44. Janis, I.L. Victims of Groupthink: A Psychological Study of Foreign-Policy Decisions and Fiascoes; Houghton, Mifflin: Boston, MA, USA, 1972.

45. Rau, H.A. The disposition effect in team investment decisions: Experimental evidence. J. Bank. Financ. 2015, 61, 272-282. [CrossRef]

46. Rau, H.A. The disposition effect and loss aversion: Do gender differences matter? Econ. Lett. 2014, 123, 33-36. [CrossRef]

47. Talpsepp, T. Does gender and age affect investor performance and the disposition effect? Res. Econ. Bus. Cent. East. Eur. 2013, 2, 76-93. 